\title{
Editorial
}

Pathobiology

Pathobiology 2007;74:1-2

DOI: 10.1159/000101045

\section{Paul Ehrlich No End: Antibodies as Therapeutic Molecules}

\author{
Bettina Borisch \\ University of Geneva Medical School, Geneva, Switzerland
}

The advent of monoclonal antibodies (mAbs) as therapeutic reagents has completely changed the prospects of some diseases [1]. This holds true for several neoplastic disorders and also for some autoimmune diseases. It has not always been like that; not so long ago, the prospects for therapeutic mAbs were not very promising. Serious problems with immunogenic reactions to mouse-derived (murine) antibodies had raised major doubts as to whether antibodies would ever emerge as a useful therapeutic option. From chimeric antibodies to humanized and finally fully human antibodies, the murine content of antibody candidates has gradually been reduced, to minimize the HAMA (human anti-mouse antigen) immunogenic response and minimize the antibody side effects. As a result of this development, reagents such as the mouse-human chimeric $\mathrm{mAb}$ directed against the B-cellspecific molecule CD20 (rituximab, Rituxan) has been introduced into clinical use, first for the treatment of Bcell non-Hodgkin lymphomas expressing CD20 at the cell surface of tumor cells. This indication has allowed to better understand the mechanisms of action of anti$\mathrm{CD} 20 \mathrm{mAb}$ [2]. In addition to the two main ways of destroying target cells, i.e. antibody-dependent cytotoxicity/complement-directed cytotoxicity and blocking receptors involved in cell growth/survival, it has been shown that binding of rituximab to CD20-positive cells moves all CD20 molecules into lipid rafts and subse-

\section{KARGER}

Fax +4161306 1234

E-Mail karger@karger.ch

www.karger.com
(C) 2007 S. Karger AG, Basel

$1015-2008 / 07 / 0741-0001 \$ 23.50 / 0$

Accessible online at:

www.karger.com/pat quently changes the behavior of raft-associated molecules such as Src kinases [3]. The downstream signalling is impaired, resulting in increased programmed cell death of the tumor cells in vitro [4]. In autoimmune disorders such as rheumatoid arthritis, B-cell depletion by rituximab caused an unexpected improvement in patients treated in such a way. This led to an extension of the indication for the clinical use of rituximab, and also to a reevaluation of the role of $\mathrm{B}$ lymphocytes in such diseases.

$\mathrm{mAbs}$ are not only relevant in the field of hematological cancers but also in the area of the far more frequent solid tumors of the breast, lung and colon. In a previous issue of this journal, Zangenmeister-Wittke [5] reviewed the role of mAbs for targeted cancer therapy in solid tumors. In that same issue, Simon et al. [6] described the results of anti-interleukin-5 antibody therapy in eosinophilic diseases.

The above-mentioned antibodies are monospecific and should recognize one single target molecule. It has been shown, however, that it may be advantageous to target simultaneously several epitopes involved in different pathways. To this end, two different antibodies can be used in combination, or bispecific antibodies can be made that will recognize two different targets. In the current issue, Fischer and Léger [7] review the technical and therapeutic aspects of these novel strategies. 
It should be mentioned that the use of $\mathrm{mAbs}$ has become an important financial factor in the pharmaceutical world and recognized as such in the economic world. The antibody sector as a whole is currently experiencing explosive growth as products finally move from the laboratory into the marketplace. Datamonitor's research (http://www.pharmaceutical-business-review.com/article_feature) indicates that the $\mathrm{mAb}$ market saw unprecedented growth of $48.1 \%$ between 2003 and 2004, taking it through the USD 10 billion barrier. Roche, together with its majority-owned US subsidiary Genentech and Japanese unit Chugai, is the uncontested leader in the $\mathrm{mAb}$ market. Genentech and Roche hold two of the top three positions in $2004 \mathrm{mAb}$ sales, with a dominant combined market share of $44.9 \%$. The Roche group's impressive first quarter results in 2005 saw its pharmaceutical sales rise by $22 \%$, thanks mainly to its oncology portfolio, incorporating the monoclonal antibodies Avastin (bevacizumab), Rituxan/MabThera (rituximab), Herceptin (trastuzumab), Xolair (omalizumab) and Raptiva (efalizumab). In the first quarter, global sales of Rituxan/ MabThera rose by 24\% to USD 749 million, Avastin sales rose by $476 \%$ to USD 210 million (after a launch approximately 1 year before), and Herceptin grew by $23 \%$ to USD 315 million, while Xolair rose by $128 \%$ to USD 65 million. In addition, the number of marketed antibodies will more than double, with 19 new companies expected to enter the market with antibody products by 2010. In the field of $\mathrm{mAbs}$, the promises of Paul Ehrlich describing $\mathrm{mAbs}$ as the 'magic bullet' of therapy have been realized in an unexpected way: they have been taken from the bench via the bedside to the business world in a very fast way and demonstrated the strength of translational research.

\section{References}

1 Koehler G, Milstein C: Continuous cultures of fused cells secreting antibody of predefined specificity. Nature 1975;256:495497.

2 Cerny $\mathrm{TB}$, Borisch B, Introna M, Johnson $\mathrm{P}$, Rose AL: Mechanism of action of rituximab. Anticancer Drugs 2002;13(suppl 2):S3-S10.
3 Ilangumaran S, Arni S, van Echten-Deckert G, Borisch B, Hoessli DC: Microdomaindependent regulation of Lck and Fyn protein-tyrosine kinases in T lymphocyte plasma membranes. Mol Biol Cell 1999;10: 891-905.

4 Semac I, Palomba C, Kulangara K, Klages N, van Echten-Deckert G, Borisch B, Hoessli DC: Anti-CD20 therapeutic antibody rituximab modifies the functional organization of rafts/microdomains of B lymphoma cells. Cancer Res 2003;63:534-540.
5 Zangemeister-Wittke U: Antibodies for targeted cancer therapy - technical aspects and clinical perspectives. Pathobiology 2005;72: 279-286.

6 Simon D, Braathen LR, Simon HU: Antiinterleukin-5 antibody therapy in eosinophilic diseases. Pathobiology 2005; 72:287292

7 Fischer N, Léger O: Bispecific antibodies: molecules that enable novel therapeutic strategies. Pathobiology 2007;74:3-14. 